\title{
Knowledge Management di InStansi PeMerintah
}

\author{
${ }^{1}$ Tri Pujadi dan ${ }^{2}$ Tumar \\ 1,2 Jurusan Sistem Informasi - Bina Nusantara University, Jl. Kebon Jeruk No 27 , Jakarta Barat 11530 \\ Indonesia \\ email: ${ }^{1}$ tripujadi@binus.edu, ${ }^{2}$ tumar@gmail.com
}

\begin{abstract}
Abstrak. Tujuan yang ingin dicapai adalah menyusun model manajemen pengetahuan di instansi pemerintahan. Kegiatan ini meng gunakan metode deskriptif dengan menggunakan metode soft system methodology. Faktor yang mendukung keberhasilan kegiatan ini adalah tersedianya data dan informasi diberbagai instansi pemerintah dan swasta. sekaligus penguasaan metodologi dalam analisis. Persaingan internasional pada saat ini cenderung lebih ketat dan kompleks, untuk itu perlu dicari cara agar mendapatkan produk atau jasa yang diperlukan oleh masyarakat. Inovasi yang kreatif dapat meningkatkan pelayanan terhadap masyarakat yang memerlukannya. Sehingga unit-unit di pemerintahan sangat tergantung dari pengelolaan pengetahuan apakah akan terjadi siklus knowledge yaitu perpindahan dari tacit ke explicit knowledge dan ke tacit knowledge. Oleh karena itu pengelolaan knowledge (knowledge management) ini menjadi penting bagi pengembangan pelayanan, karena masyarakat semakin kritis dan cerdas dan meningkatkan kemampuan sumber daya manusia bagi pemangku kepentingan.
\end{abstract}

Kata kunci : Model, knowledge management, instansi pemerintahan

\section{Pendahul uan}

Teknologi informasi berkembang pesat, membuat masyarakat semakin kritis dan dinamis, hal ini berarti meningkat pula pengetahuan mereka. Instansi pemerintah dituntut meningkatkan pelayanan yang memuaskan, sehingga diperlukan penguasaan pengetahuan yang memadai untuk menjawab tantangan tersebut.

Pengembangan pengetahuan dimulai dari pengembangan perorangan pribadi; dimana pola berpikir dan perilaku secara pribadi berpangkal pada suatu tingkat kualitas yang jelas. Implikasi hal ini ialah bahwasannya seseorang harus selalu memperbaiki dan meningkatkan kualitas diri dalam konteks ilmu pengetahuan, sebab apa yang diperoleh selama pendidikan formal di tingkat strata satu, akan pudar dalam waktu 3 atau 4 tahun. Apabila tidak meningkatkan diri dengan ilmu pengetahuan dan sains baru maka pasti akan tertinggal. Demikian pula dengan keterampilan profesionalisme, berkembangnya teknologi, rnisalnya dalarn bidang komputer, sistem informasi manajemen, ComputerAided Design / Computer Aided Manufaciuring, Internet, Office Automation dan lainnya; mempunyai implikasi perlunya peningkatan kualitas keahlian yang cepat.

Hubungan interpersonal dalam setiap organisasi sangat penting dan menentukan harmoni organisasi maupun dalam konteks kerjasama tim. Hubungan yang harmonis ini hanya akan tercapai apabila setiap orang berusaha meningkatkan kualitas diri untuk dapat memberikan kontribusi yang berkualitas dan memadai dalam rangka mengembangkan sinergi organisasi. Kualitas kerjasama menentukan keberhasilan tim dalam memecahkan masalah karena : (a) Kerjasama suatu tim mempunyai dampak lebih besar daripada hasil perorangan. (b) Anggota tim akan lebih dimotivasi dalam kelompok 
dibandingkan individu. (c) Untuk menghadapi persaingan global dan memecahkan masalah organisasi yang rumit diperlukan tim dengan anggota lintas fungsional. Kualitas keterampilan tim lintas fungsional akan lebih baik apabila hubungan interpersonal tim ialah harmonis dan sating menunjang secara komplementer dan kolektif.

Dengan latar belakang di atas, penelitian bertujuan mengembangkan model pengelolaan pengetahuan, agar tercapai manajemen yang baik dalam mendukung visi, misi dan tujuan organisasi. Model tersebut akan meningkatan kualitas hasil kerja dan daya saing organisasi secara konsisten dengan pengukuran secara kontinyu atas semua tahapan, akan tetapi tanpa menambah biaya dan dapat mengurangi pemborosan waktu, dana dan kerugian lainnya, dengan demikian telah tercapai tingkat efektivitas managerial. Efektivitas memerlukan pengukuran hasil kerja. Pengukuran dilakukan terhadap kinerja yang lampau maupun terhadap tingkat rata-rata untuk memperoleh fakta dan data seberapa jauh terjadi peningkatan efektivitas untuk kurun waktu yang relatif sama.

\subsection{Komunikasi dalam Manajemen}

Komunikasi dalam manajemen adalah salah satu tanggung jawab yang penting dari setiap manajer. Seringkali efektivitas terletak pada keahlian dalam komunikasi gagasan. Komunikasi adalah pekerjaan yang dilakukan oleh manajer dalam menjelaskan pengertian antara manajer dan orang lain. Proses komunikasi dalam manajemen merupakan proses minta, betitahukan, dengar dan mengerti.

Dalam kontek evolusi perkembangan keberhasilan manajemen perusahaan tak lepas dari perilaku manusia yang memegang peranan. Hubungan manusia dengan organisasi menggunakan istilah perilaku administrasi, meskipun perkembangan mutakhir, ilmu ini berkembang menjadi perilaku organisasi. Hal ini karena, pada dasarnya organisasi meliputi kerjasama antara dua orang atau lebih yang bertujuan mencapai sesuatu dengan menggunakan teknologi, struktur dan proses.

Perilaku organisasi adalah kaitan unsur-unsur antara manusia, struktur, proses, tehnologi dan tujuan seperti nampak dalam gambar-1 di bawah ini.

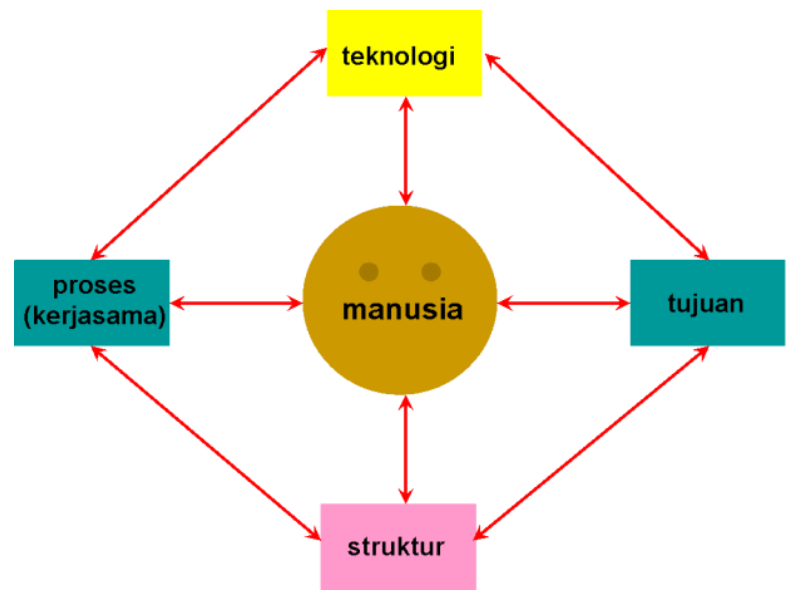

Gambar 1. Diagram Pe rilaku Organisasi 


\subsection{Knowledge Management}

Knoowledge Management atau 'Manajemen Pengetahuan atau KM", memerlukan relasi antar manusia yang baik, hal ini berhubungan dengan studi yang tentang manusia. Tentu saja suatu bagian disiplin ilmu atau bidang-bidang, seperti filsafat, sosiologi, ilmu politik dan agama. Adapun istilah human relationship mempengaruhi berbagai pengertian, antara lain diartikan : 1) komunikasi; 2) sinonim untuk sosiologi industri; 3) pendekatan interdisiplin terhadap hubungan di dalam industri; dan 4) pendekatan etik terhadap masalah personal atau terhadap hubungan dalam industri.

Sebuah manajemen pengetahuan dapat dilihat dari tiga pandangan yang berbeda dimana setiap pimpinan mempunyai persepsi berbeda dalam perhitungan dan definisinya.

Dari perspektif bisnis (Barclay and Murray, 1997), manajemen pengetahuan merupakan aktifitas bisnis dengan dua aspek utama, yaitu perlakuan komponen pengetahuan dari aktifitas bisnis secara eksplisit pada refleksi perhatian bisnis dalam strategi, aturan dan prakteknya pada semua level organisasi; dan membuat hubungan langsung antara aset intelektual organisasi disebut eksplisit dan pengetahuan individu disebut tacit dan hasil bisnis yang positif. Manajemen pengetahuan (Grey, 1996) adalah pendekatan sebuah kolaborasi dan integrasi dari penciptaan,tangkapan, organisasi, akses dan penggunaan aset intelektual perusahaan.

Dari perspektif kognitif (Wiig, 1993, halaman 38-19), wawasan pengetahuan, pemahaman, dan praktek untuk mengetahui segala kemungkinan - adalah sumber daya utama yang membolehkan kita pada fungsi intelektual. Lebih lagi, pertimbangan pengetahuan juga ditransfer pada manifestasi lain seperti buku, teknologi, praktik, dan tradisi di dalam organisasi dan masyarakat pada umumnya. Hasil dari transformasi dalam akumulasi ahli, bila digunakan dengan tepat, meningkatkan keefektifan.

Dari perspektif teknologi (Information Week, Sept. 1, 2003), manajemen pengetahuan adalah konsep dimana informasi diubah menjadi tindak lanjut pengetahuan dan memudahkan orang yang menerapkannya. Peningkatan kebijaksanaan kolektif untuk meningkatkan respon dan inovasi.

Pengertian lebih praktis (Steve Ward, Northrop Grumman), manajemen pengetahuan adalah pendekatan sistematis untuk mengolah informasi untuk memberikan kelanjutan alur dari pengetahuan pada orang dan waktu yang tepat memungkinkan pengambilan keputusan yang efisien dan efektif dalam keseharian bisnis mereka.

Secara historis, pengetahuan selalu diolah, setidaknya implikasinya. Oleh karena itu, manajemen pengetahuan efektif dan aktif membutuhkan perspektif dan teknik baru dan menyentuh hampir semua aspek organisasi. Kita butuh untuk mengembangkan sebuah disiplin ilmu dan mempersiapkan kader professional pengetahuan dengan keahlian kita sebelumnya (Wiig, in Grey, 1996).

Pada Gambar-2 manajemen pengetahuan terdiri gabungan dari strategi, alat dan teknik. Penceritaan, bimbingan dan belajar dari kesalahan, misalnya, Semua yang bisa dijadikan teladan dalam pendidikan, pelatihan dan praktek kecerdasan buatan. Manajemen pengetahuan memanfaatkan gabungan dari teknik - teknik dari 
pengetahuan berbasis desain system, seperti strategi pengetahuan terstruktur dari ahli materi pelajaran (McGraw dan Horrison - Brigs, 1989) dan teknologi.

Gambar 2. Sifat Interdisiplin dari Manajemen Pengetahuan

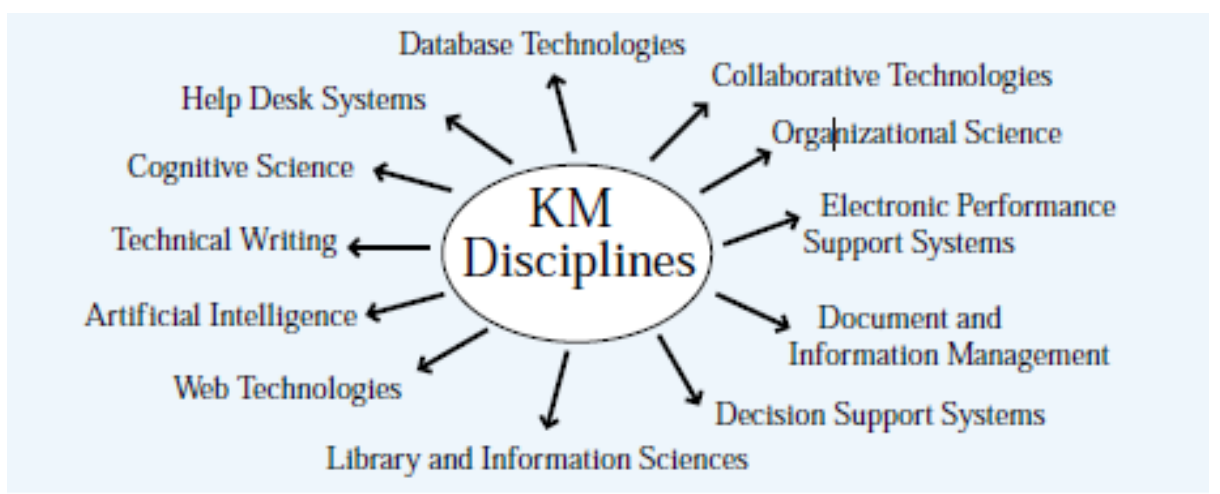

Sumber : Brigs, 1989

Salah satu atribut utama dari KM berhubungan pada fakta bahwa itu berurusan dengan pengetahuan sebagaimana informasi. Pengetahuan adalah cara yang lebih subjektif dari pengenalan dan biasanya didasarkan pada pengalaman dan nilai individual, persepsi dan pengalaman. Contoh umum untuk membedakan data dari informasi dan dari pengetahuan antara lain meliputi :

Data atau masukan, yaitu konten yang secara langsung di observasi dan di verifikasi, berisi fakta, diunduh daftarnya. Informasi berisi konten yang merupakan hasil analisa data. Pengetahuan, memuat atribut yang langsung maupun tidak langsung dengan pengetahuan.

Pengetahuan tacit sangat sulit diartikulasikan dan juga sulit di masukkan kedalam bentuk kata, text atau gambar. Sebaliknya, pengetahuan eksplisit mewakili konten yang dapat ditangkap dalam bentuk kata, rekaman suara atau gambar. Lebih dari itu, pengetahuan tacit cenderung berada di dalam kepala yang mengetahui, sedangkan pengetahuan eksplisit biasanya dimuat dalam media nyata atau konkrit. Konten yang sama dapat eksplisit untuk satu orang namun tidak bagi orang lain. Asas berlawanan berperan disini. Disatu sisi, ketrampilan, pengalaman dan keahlian individu yang sangat tinggi mungkin sulit untuk diartikulasikan pengetahuannya. Awalnya, cenderung mudah membedakan apa yang mereka lakukan karena biasanya berdasarkan manual atau bagaimana prose situ dilakukan.

Model mental adalah asumsi, generalisasi, atau bahkan gambaran atau imajinasi yang sa-ngat melekat yang mempengaruhi bagaimana kita memahami dunia dan bagaimana kita bertindak. Model mental berfungsi untuk membentuk bagaimana kita bertindak, dan be-gitu kuat karena mempengaruhi apa yang kita lihat, serta berfungsi untuk menempa ber-pikir sistem. Masalah yang terjadi biasanya dengan model mental adalah bukan kare-na ia benar atau tidak, tetapi ketika model tersebut bersifat tacit. Untuk mengatasinya, mo-del mental dimulai dengan membalik cermin ke dalam, lalu belajar menggali gambar diri kita tentang dunia untuk membawanya ke permukaan dan lalu menjaganya dengan cer-mat untuk diteliti. Selanjutnya ia mencakup kemampuan 
untuk melaksanakan percakap-an pembelajaran yang menyeimbangkan pertanyaan (inquiry) dan pembelaan (advocacy)

Untuk mengembangkan kemampuan organisasi bekerja dengan model mental maka diperlukan dua hal, yakni mempelajari ketrampilan baru dan menerapkan inovasi institusional. Keduanya dilakukan dengan mengangkat permukaan model dan mengembangkan pembelajaran tatap muka. Untuk itu, perlu dikembangkan pengelolaan di dua tingkatan. Pertama, mengelola pada tingkatan organisasi secara menyeluruh dengan dua strategi, yakni perencanaan sebagai pembelajara, dan Dewan Internal. Kedua, mengelola pada tingkatan pribadi dan antar pribadi dengan meningkatkan ketrampilan refleksi dan pertanyaan. Ketrampilan ini dapat ditingktkan melalui : leaps ofabstraction atau lompatan abstraksi (ketika kita pindah dari observasi langsung menuju generalisasi tanpa pengujian), lefthand column (satu teknik untuk memulai melihat bagaimana model mental berjalan dalam situasi khusus yang mengungkap cara kita memanipulasi situasi untuk menghindari berurusan dengan bagaimana kita sesungguh-nya berpikir dan merasa sehingga mencegah situasi kontraproduktif berkembang), menyeimbangkan pertanyaan dan pembelaan (saling bertanya dan menjawab sehingga mencapai kesepahaman dan mengekplisitkan pikiran yang tersembunyi), dan espoused theory versus theory-in-use (mencapai kesamaan antara apa yang diucapkan dengan teori apa yang sebenarnya berada dibalik tindakan kita).

\section{Metode Kegiatan}

Pembuatan desain model diawali dengan penelitian deskriptif, untuk membuat deskripsi secara sistimatis dan akurat. Mencari informasi faktual pada instansi yang terkait secara detail, mengidentifikasi masalah-masalah atau mendapatkan justifikasi keadaan dan kondisi yang ada dalam implementasinya pelayanan masyarakat. Kemudian membuat komparasi dan evaluasi untuk mengetahui apakah yang dikerjakan selama ini dirasakan oleh para karyawan pemerintah terlalu berat.

\section{Hasil dan Pembahasan}

Model merupakan hal penting untuk mengungkapkan dan menyelesaikan persoalan utama yang berdiri diantara suatu gagasan dengan implementasi yang berhasil. Terdapat beberapa isu penting yang berkenaan dengan prototipe ini, antara lain: keterbukaan, kelokalan, waktu manajer, mengakhiri perang antara kerja dan keluarga, microwords, pekerjaan baru pemimpin.

Keterbukaan merupakan situasi yang mencerminkan norma pembicaraan yang terbuka dan jujur tentang isu-isu penting, dan kemampuan untuk menantang pikiran sendiri secara berkesinambungan. Meliputi keterbukaan parsipatif, yaitu memperbincangkan pikiran seseoarang dan keterbukaan reflektif, yaitu kemauan untuk menantang pikiran sendiri, untuk mengakui adanya kepastian bahwa kita pernah memiliki suatu hipotesis tentang dunia ini. Kelokalan berati perluasan derajat kewenangan dan kekuasaan sejauh mungkin dari puncak atau pusat organisasi. Melalui pembelajaran, organisasi menerapkan kelokalan akan mencapai kontrol dengan tanpa melakukan kontrol kelokalan ini akan menghadapi rintangan ilusi being in control yang 
mengungkap bahwa seseorang mampu menguasai kompleksitas dinamis dan detail seluruh organisasi dari puncak.

Isu tentang waktu manajer karena walu bagaimanapun pembela-jaran membutuhkan waktu dan tak ada seorangpun yang tahu berapa lama waktu yang dibutukan manajer untuk melakukan refleksi, membuat model, dan mendesain proses pembelajaran. Untuk itu harus disediakan keleluasaan waktu bagi manajer untuk berproses dalam organisasi pembelajaran.

Isu berikutnya dalam prototipe pembelajaran adalah berkaitan dengan upaya mengakhiri perang antara kerja dan keluarga. Selama ini, kita dihadapkan pilihan berkarier tapi kehilangan keluarga, atau memilih keluarga dengan resiko hilangnya karier. Melalui organisasi pembelajaran maka perang tersebut akah berakhir. Penguasaan pribadi dan pembelajaran berkembang sekaligus baik di rumah dan tempat kerja. Penguasaan atas struktur ketidak seimbangan antara kerja dan keluarga membawa kita pada pengungkitan yang menyeimbangkan pembagian waktu yang memadai diantara keduanya. Ada dua tingkatan yang dapat melakukan penyeimbangan tersebut, yakni individu dan organisasi. Individu berperan menyeimbangkan antara kerja dan keluarga dengan menggunakan prinsip penguasaan pribadi dan pendaftaran, yang meliputi: identifikasi apa yang sebenarnya penting bagi anda, lalu membuat pilihan (komitmen), kemudian yakinlah dengan apa yang anda pilih, dan yang terakhir jangan memanipulasi. Organisasi berperan juga dengan melakukan beberapa langkah: mendukung penguasaan pribadi sebagai strategi dan falsafah organisasi; memungkinkan masuknya isu keluarga seperti halnya isu pekerjaan kedalam diskusi, terutana yang berkaitan dengan penempaan komitmen waktu; bila diperlukan, bantulah orang-orang untuk memperoleh arahan dan bimbingan untuk mengefektifkan pemanfaatan waktu keluarganya. Gambar-3 menjelaskan model knowledge management di Instansi Pemerintahan.

Isu prototipe lainnya adalah microworlds, yang memungkinkan organisasi untuk melakukan learning by doing dalam menerapkan organisasi pembelajaran. Microworlds memadatkan waktu dan ruang sehingga memungkinkan untuk bereksperimen dan mempelajari konskuensi dari pengambilan keputusan kita di masa depan dan bagian lain dari organisasi kita. Ada tiga jenis microworlds yang bisa diterapkan: pertama, pembelajaran masa depan, guna mengungkapkan kontrakdiksi internal dalam suatu strategi. Kedua, melihat peluang strategi yang tersembunyi, yang membantu kita untuk menjelaskan bagaimana kepercayaan kita mempengaruhi prereferensi konsumen kita. Ketiga, mengungkapkan pengungkit yang belum dimanfaatkan. Terdapat beberapa isu kunci yang dipelajari mengenai microworlds ini dalam organisasi pembelajaran, yaitu : integrasi microworlds dengan dunia nyata, mempercepat atau memperlambat waktu, mempersempit ruang, isolasi variabel, orientasi eksperimen, jeda refleksi, strategi berbasis teori, dan memori kelembagaanya.

Isu terakhir yang berkaitan dengan prototipe adalah peran baru dari pemimpin. Dalam organisasi pembelajaran pemimpin dapat bertindak sebagai desainer dan sekaligus guru. Peran pertama menempatkannya sebagai pemain kunci dalam mengintegrasikan lima disiplin pembelajaran, selain itu, ia berperan pula untuk menyusun desain agar segala sesuatunya dapat bekerja ketika dipraktekan. Peran kedua membuatnya harus mendefinisikan realitas bisa dipandang berbeda oleh setiap orang 
yang berada dalam organisasi. Selain itu, ia harus pula memberikan teleological explanations, yang berarti penjelasan terhadap tujuan dan sasaran yang hendak dicapai oleh organisasi. Sebagai penjelas tentu ia tidak memainkan peran untuk menentukan secara arbitrary tujuan dan sasaran tersebut.

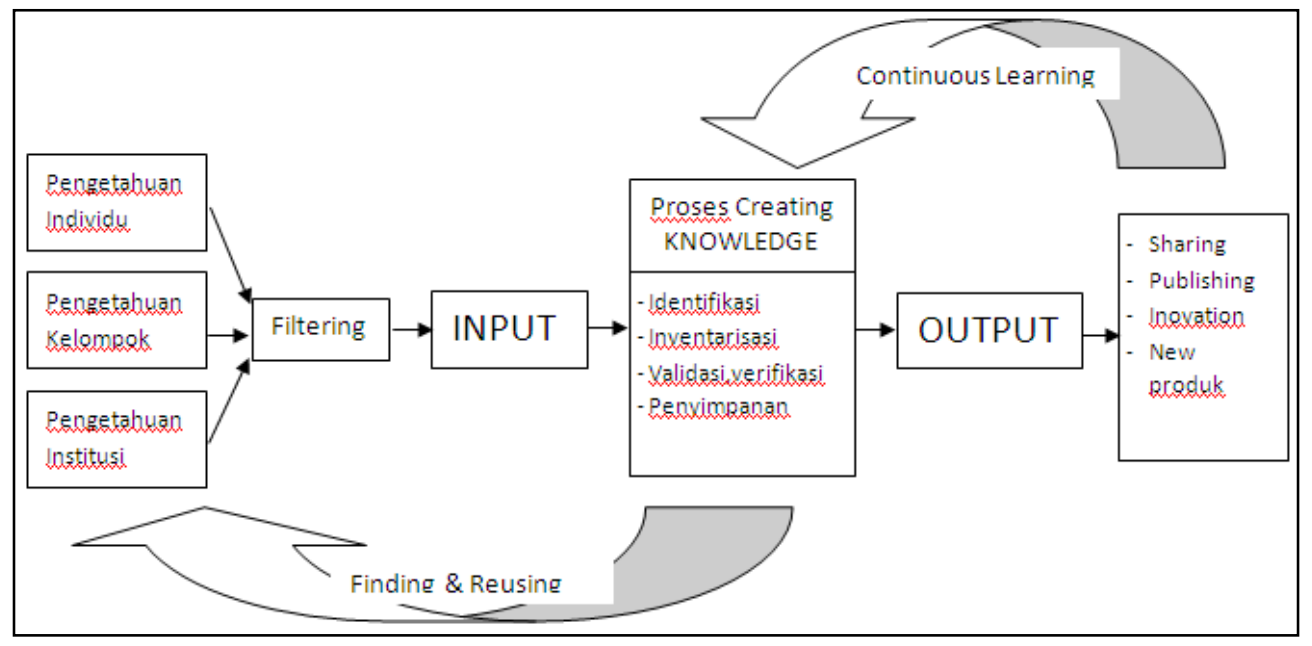

Gambar 3. Model Knowledge Management di Pemerintahan

Sebagai masukan (Input) adalah seluruh pengetahuan individu di dalam organisasi, pengetahuan yang dimiliki tim kerja dalam organisasi dan berbagai informasi serta pengetahuan yang terdapat didalam institusi. Sebagai contohnya, pengetahuan dan keterampilan individu dan kelompok dalam menyusun dan melakukan pemantauan anggaran proyek-proyek di pemerintahan; serta berbagai peraturan yang menjadi dasar pelaksanaan tugas menyusun anggaran.

Seluruh informasi dan data tadi dilakukan pemilihan (filtering), untuk dijadikan masukan ke dalam model manajemen pengetahuan di instansi pemerintahaan ini

Adapun PROSES, terdiri dari masukan berupa data dan informasi individu dan kelompok serta data institusi selanjutnya dilakukan proses identifikasi, inventarisasi, selanjutnya diklasifikasikan, dilakukan validasi dan verifikasi untuk memperoleh informasi yang sesuai dengan keperluan setiap individu, kelompok dan organisasi. Apabila perancangan model informasi pengetahuan ini telah berhasil dilakukan selanjutnya disimpan di dalam repository pengetahuan.

Hasil atau OUTPUT berupa pengetahuan yang telah disimpan dalam basisdata pengetahuan, selanjutnya dapat diguankan untuk pemakaian bersama, dipublikasi, digunakan untuk melakukan invovasi dan menghasilkan produk atau komoditas baru. Aktifitas pembentukan pengetahuan sampai dengan penggunaannya ini dilakukan terus menerus sebagaimana sebuah siklus proses pengetahuan

Proses penyiapan informasi pengetahuan mencakup bagaimana menemukan dan menggunakan kembali data dan informasi tersebut yang memperlihatkan siklus antara proses dengan masukan. Sedangkan penggunaan pengetahuan dalam pembelajaran berkelanjutan, memanfaatkan keluaran dari model untuk secara terus menerus menghasilkan pengetahuan baru untuk di proses melalui tahapan identifikasi, inventarisasi, klasifikasi, validasi dan verifikasi dan diakhiri dengan menyimpan di repository 


\section{Simpulan}

Melalui model manajemen pengetahuan di pemerintahan, setiap individu sebagai pemangku kepentingan yang melayani masyarakat, akan memiliki pengetahuan yang memadai, dalam melksanakan tugasnya. Pengetahuan dipandang sebagai sebuah komoditi atau sebuah aset intelektual.

Penggunaan pengetahuan tidak akan menghabiskan pengetahuan, sebab semakin sering digunakan pengetahuan akhirnya semakin berkembang, secara luas yang akhirnya seseorang tidak tergantung pada seseorang yang memiliki pengetahuan. (continuous learning)

Perpindahan pengetahuan tidak akan menghilangkan pengetahuan, sebab pengetahuan yang dimiliki seseorang tidak serta merta akan hilang jika terjadi tranfer pengetahuan keseseorang. Melalui model ini, pengetahuan itu berlimpah, tetapi kemampuan terbatas untuk menggunakannya akan dapat dihindari; dan mengurangi kemungkinan hilangnya pengetahuan, karena tidak digunakan dan transfer pengetahuan tidak terjadi

\section{Daftar Pus taka}

Barclay and Murray, Al-Hawamdeh, S. (1997). Knowledge management: cultivating knowledge professionals. Rollinsford, NH: Chandos Publishing.

Davenport, T. H., and Prusak, L. (1998). Working knowledge: how organizations manage what they know. Boston: Harvard Business School Press.

Grey, Groff, T., and Jones, T. (2003). Introduction to knowledge management. Boston:

Butterworth-Heinemann.

Brigs , Mark W. Mc. Elroy (1989). The New Knowledge Management : Complexity, Learning and Sustainable Innovation, Butterworth Heinemann, USA. ISBN : 978-0750676083

McElroy, M. (2002). Ethics, innovation and the open enterprise. Knowledge Management, 6(1). Available at http://www.kmmagazine.com/xq/asp/sid.0/article id.

Rusonow, G. (2003). Knowledge management and the smarter lawyer. New York:

ALM Publishing.

Wiig, D. Bonner (Eds.), In action: leading knowledge management and learning, pp.

55-70. Alexandria, VA: American Society for Training and Development.

Zhitian Zhou, Feipeng Gao (2007), E-government and Knowledge Management, IJCSNS International Journal of Computer Science and Network Security, VOL.7 No.6, June 2007 